\title{
ANALISIS MODEL DIVERSI MELALUI RESTORATIVE JUSTICE PADA ANAK PELAKU TINDAK PIDANA TERORISME DALAM PERSPEKTIF MAQASHID SYARI'AH
}

\author{
Mohammad Farid Fad \\ UIN Walisongo Semarang | JI.Walisongo No.3-5, Semarang | \\ mohammadfarid@walisongo.ac.id
}

\begin{abstract}
The act of terrorism involving children certainly raises its own concerns. How not, if the child is faced with a formal justice process then besides he will lose his independence, he will also lose his future because of stigmatization as a terrorist who is attached for life. However, if the model of diversion through restorative justice is adopted, the legal process will be blocked by the provisions of Article 7 paragraph (2) of Law No. I I of 2012 concerning the Child Criminal Justice System. Then what is the meeting point between the two? How is this diversion approach in the perspective of Maqashid al-Shari'ah? This article tries to describe the diversion model through a restorative justice approach in the perspective of maqashid al-shariah. The type of method used in this study is a qualitative method. The data collection technique used is library research sourced from various literatures such as books, books and journal articles. After the data is collected, an analysis will be carried out using descriptiveanalytical methods. This study concludes that restorative justice through a diversion model is in line with the principles of maqashid al-syariah, this legal approach aims to help children of terrorists realize, feel and restore humanitarian relations that were damaged between the perpetrators and victims. This is due to the fact that the child of the terrorist is not an actor in the real sense, but he is the real victim of the results of his parents' indoctrination or other parties.

Keywords: restorative justice, diversion, terorism, maqāshid al-syarī'ah
\end{abstract}


Abstrak: Aksi terorisme yang melibatkan anak-anak tentu mengundang keprihatinan tersendiri. Bagaimana tidak, bila anak tersebut dihadapkan pada proses peradilan formil maka selain ia akan kehilangan kemerdekaannya, juga kehilangan masa depannya karena stigmatisasi sebagai pelaku teror yang dilekatkan seumur hidup. Namun bila ditempuh model diversi melalui keadilan restoratif maka dalam proses hukumnya akan terhadang oleh ketentuan Pasal 7 ayat (2) UU No. II Tahun 2012 tentang Sistem Peradilan Pidana Anak. Lalu bagaimanakah titik temu antara keduanya? Bagaimanakah pendekatan diversi ini dalam perspektif Maqâshid al-Syarî‘ah? Artikel ini mencoba untuk mendeskripsikan model diversi melalui pendekatan restorative justice dalam perspektif maqâshid alsyari 'ah. Jenis metode yang digunakan dalam penelitian ini adalah metode kualitatif. Teknik pengumpulan data yang digunakan adalah telaah pustaka (library research) yang bersumber dari berbagai literatur seperti buku-buku, kitab dan artikel jurnal. Setelah data terkumpul, akan dilakukan analisis dengan menggunakan metode deskriptif-analitis. Penelitian ini menyimpulkan bahwa keadilan restoratif melalui model diversi selaras dengan prinsip-prinsip maqâshid al-syarî‘ah, pendekatan hukum ini bertujuan untuk membantu anak pelaku teror menyadari, merasakan sekaligus memulihkan kembali hubungan kemanusiaan yang sempat rusak antara pelaku dan korban. Hal ini disebabkan pada dasarnya anak pelaku teror bukanlah pelaku dalam arti sebenarnya, namun ia adalah korban sesungguhnya dari hasil indoktrinasi orangtuanya ataupun pihak lain.

Kata Kunci: restorative justice, diversi, terorisme, maqāshid al-syarī'ah

\section{Pendahuluan}

UNICEF memperkirakan bahwa lebih dari 1 juta anak berada di balik jeruji besi di seluruh dunia ${ }^{1}$. Selama proses selanjutnya dalam sistem peradilan anak, efek berbahaya dapat timbul, seperti stigmatisasi hukuman pidana. Anak sebagai pelaku tindak pidana akan diberi labelisasi berupa penjahat kriminal yang berdimensi seumur hidup. Tak hanya itu, pelaku tindak pidana anak akan

\footnotetext{
' Human Rights Watch, Children Behind Bars, The Global Overuse of Detention of Children, https://www.hrw.org/world-report/2016/children-behind-bars
} 
berpotensi meningkatkan angka residivis pelaku kejahatan di masa mendatang.

Padahal anak merupakan penerus cita-cita perjuangan suatu bangsa, selain itu anak merupakan harapan orang tua, harapan bangsa dan negara yang akan melanjutkan tongkat estafet pembangunan bangsa serta memiliki peran strategis, mempunyai ciri atau sifat khusus yang akan menjamin kelangsungan eksistensi bangsa dan negara pada masa depan. Setiap anak harus mendapatkan pembinaan sejak dini dan anak perlu mendapat kesempatan yang seluas-luasnya untuk dapat tumbuh dan berkembang secara optimal, baik fisik, mental maupun sosial. Terlebih lagi bahwa masa kanak-kanak merupakan periode pembentukan watak, kepribadian dan karakter diri seorang manusia, agar kehidupan mereka memiliki kekuatan dan kemampuan serta berdiri tegar dalam meniti kehidupan. ${ }^{2}$

Memang, seiring pertumbuhannya, anak seringkali terpengaruh oleh lingkungan sosialnya tempat ia bergaul dan bersosialisasi. Tak jarang awalnya berbudi pekerti baik, namun karena terpapar pengaruh teman sepergaulan berubah menjadi nakal, bahkan melakukan perilaku menyimpang yang dapat dikategorikan sebagai tindak pidana. Ujungnya, ia akan berhadapan dengan proses hukum yang terlalu berat bagi seusianya.

Secara teoritis, anak yang berhadapan dengan hukum (children in conflict with the law), dimaknai sebagai seseorang yang berusia dibawah 18 tahun yang berhadapan dengan sistem

\footnotetext{
2 Maidin Gultom, Perlindungan Hukum Terhadap Anak dalam Sistem Peradilan Pidana Anak di Indonesia, (Bandung: Refika Aditama, 20 I4), I.
} 
peradilan pidana dikarenakan yang bersangkutan disangka atau dituduh melakukan tindak pidana. ${ }^{3}$

Terdapat perbedaan definisi tentang konsep anak menurut hukum positif dan hukum Islam. Pada diskursus hukum positif, anak diartikan sebagai orang yang belum dewasa (minderjarig/person under age), orang yang di bawah umur atau keadaan di bawah umur (minderjarig heid/inferiority) atau biasa disebut juga sebagai anak yang berada di bawah pengawasan wali (minderjarige under voordij) $)^{4}$. Atau dengan kata lain, anak adalah sebutan bagi mereka yang belum dewasa dan yang menjadi dewasa karena peraturan tertentu meskipun mental, fisik masih belum dewasa. ${ }^{5}$

Sementara definisi anak dalam hukum Islam dikenal sebagai seseorang yang belum mencapai umur baligh. Artinya, orang tersebut belum mencapai batasan umur yang perbuatannya bisa dipertanggungjawabkan secara hukum (ahliyyatul ad $\hat{a}^{\prime}$ ).

Menurut Pasal 1 ayat (3) UU No. 11 Tahun 2012 disebutkan bahwa anak yang berkonflik dengan hukum adalah anak yang berumur 12 (dua belas) tahun, tetapi belum berumur 18 (delapan belas) tahun yang diduga melakukan tindak pidana.

Dalam perspektif Konvensi Hak Anak /KHA (Convention The Rights of The Children / CRC), anak yang berkonflik dengan hukum dikategorikan sebagai anak dalam situasi khusus (Children in Need of Special Protection / CNSP). UNICEF menyebut anak dalam kelompok ini sebagai children in especially difficult circumtances (CDEC), karena kebutuhan-kebutuhannya tidak terpenuhi, rentan mengalami tindak kekerasan, berada di luar lingkungan keluarga (berada pada lingkup otoritas institusi negara), membutuhkan

\footnotetext{
${ }^{3}$ UNICEF, Child Protection Information Sheet, (Child Protection Information Sheet, 2006).

${ }^{4}$ Aras Firdaus, "Perlindungan Hukum bagi Anak Pelaku Tindak Pidana Kejahatan Seksual Melalui Diversi dalam Sistem Peradilan Anak (Juvenile justice System)", USU Law Journal, Vol. 4, No. 3, Juni 2016, I.

${ }^{5}$ Shanty Dellyana, Wanita Dan Anak Di Mata Hukum, (Yogyakarta: Liberty, 1988), 50
} 
proteksi berupa regulasi khusus serta membutuhkan perlindungan dan keamanan dirí.

Selama ini, model pemidanaan berdasarkan Undang-Undang No. 11 Tahun 2012 tentang Sistem Peradilan Pidana Anak ini lebih menekankan pendekatan retributive justice, artinya lebih mengedepankan paradigma penangkapan, penahanan, dan penghukuman penjara terhadap anak pelaku terorisme.

Padahal, dalam konstruksi hukum pidana yang dibangun berdasar paradigma retributif, penderitaan atau kerugian yang dialami oleh korban terorisme telah diabstraksikan dan dikompensasikan dengan ancaman sanksi pidana yang diancamkan pada pelaku. Abstraksi terhadap kerugian atau penderitaan korban serta kewenangan penyelesaian tindak pidana dalam jalur hukum yang hanya dimiliki oleh aparat penegak hukum tersebut tidak terlepas dari pengertian tindak pidana yang menurut pandangan retributif dikonsepsikan sebagai perbuatan yang melanggar hukum negara. ${ }^{7}$

Menurut pandangan retributif, konstruksi penyelesaian tindak pidana akan menghadap-hadapkan anak sebagai pelaku, melawan negara, sebagai pihak yang aturan hukumnya telah dilanggar. Padahal sejatinya, anak pelaku terorisme hanyalah korban indoktrinasi orang tua ataupun orang lain, dan bukan pelaku dalam arti sesungguhnya. Hal itu dikarenakan anak yang melakukan tindak pidana teror, harus ditafsirkan karena ketidakmampuan akal (pikiran), atau moral dan kestabilan mentalitas yang ada pada diri sang anak.

\footnotetext{
${ }^{6}$ Adi Hardiyanto Wicaksono, "Kebijakan Pelaksanaan Diversi Sebagai Perlindungan Bagi Anak Yang Berkonflik dengan Hukum Pada Tingkat Penuntutan Di Kejaksaan Negeri Kudus", Jurnal Law Reform, Volume II Nomor I Tahun 20 I 5, I4.

${ }^{7}$ G. Widiarta, "Ide Keadilan Restoratif Pada Kebijakan Penanggulangan kekerasan Dalam Rumah Tangga dengan Hukum Pidana", Ringkasan Disertasi, (Program Doktor Ilmu Hukum Universitas Diponegoro, 2011), 14.
} 
Dapat dikatakan bahwa proses peradilan pidana terhadap anak pelaku teror dalam penjatuhan pidana adalah ultimum remedium dan bukan primum remedium, tujuan proses peradilan pidana anak bukanlah ditujukan pada penghukuman, melainkan perbaikan kondisi, pemeliharaan dan perlindungan anak serta pencegahan pengurangan tindakan pengadilan yang konstruktif. ${ }^{8}$

Hal itu disebabkan proses penghukuman yang diberikan kepada anak lewat sistem peradilan pidana formal dengan memasukkan anak ke dalam penjara terbukti tidak berhasil menjadikan anak jera dan menjadi pribadi yang lebih baik untuk menunjang proses tumbuh kembangnya. Penjara justru seringkali membuat anak semakin profesional dalam melakukan tindak kejahatan. ${ }^{9}$

Dari sinilah muncul kesadaran terhadap ketidakmampuan praktik peradilan pidana untuk menangani dampak psikis terhadap anak pelaku tindak terorisme telah membuat banyak orang mempertimbangkan keadilan restoratif sebagai alternatif solusi. Restorative justice memberikan penegasan bahwa anak yang berkonflik dengan hukum bukan untuk dihukum melainkan harus dibimbing dan dibina agar dapat menjadi anak yang lebih baik, karena tujuan utama dari restorative justice adalah pemulihan atau mengembalikan kepada kondisi semula dan memberikan kesempatan kepada anak untuk mempertanggungjawabkan atas sesuatu yang telah ia lakukan. ${ }^{10}$

Dengan kondisi demikian, banyak ahli hukum mendorong penerapan penyelesaian kasus anak pelaku tindak pidana

${ }^{8}$ Dwidja Priyatno, Wajah Hukum Pidana Asas dan Perkembangan, (Bekasi: Gramata Publishing, 2012), 308.

9 M. Joni \& Zulchaina Z. Tanamas, Aspek Hukum Perlindungan Anak Dalam Perspektif Konvensi Hak Anak, (Bandung: Citra Aditya Bakti, 1999), I.

${ }^{10}$ Reyner Timothy Danielt, "Penerapan Restorative Justice Terhadap Tindak Pidana Pencurian di Bawah Umur", Lex et Societas, Vol. II, No.6/ Juli 2014, 17. 
terorisme melalui restorative justice (al-isti'adah) dengan menggunakan model diversi. Dengan pendekatan restorative justice melalui model diversi memberikan peluang besar untuk menjauhkan anak dari proses peradilan yang tidak diperlukan demi menjaga jiwa, moral, dan masa depan anak tersebut. Dikarenakan secara prinsip, pengalihan dari proses litigasi menuju proses non-litigasi terhadap anak yang melakukan tindak pidana terorisme akan menghindarkan anak dari dampak negatif pemidanaan.

Untuk itu, artikel ini akan memfokuskan pada model diversi melalui restorative justice pada anak pelaku tindak pidana terorisme dalam perspektif maqâshid syarî' $a h$.

\section{Metode Penelitian}

Jenis metode yang digunakan dalam penelitian ini adalah metode kualitatif. Penelitian ini bertujuan untuk menganalisis model diversi melalui restorative justice pada anak pelaku tindak pidana terorisme dalam perspektif maqâshid syarî'ah. Setelah data terkumpul, dianalisis dengan menggunakan metode deskriptifanalitis, yaitu menggambarkan secara sistematis fakta atau karakteristik fenomena yang ditemukan dilapangan secara faktual dan cermat, serta dilakukan analisis secara kualitatif untuk mendapatkan pemahaman terhadap permasalahan yang diteliti secara lebih mendalam.

\section{Pembahasan}

Dalam sejarahnya, mulai awal hingga pertengahan 1970an, ketika program rekonsiliasi korban-pelaku pertama kali didirikan di Kanada dan Amerika bagian Barat-Tengah-tepatnya ketika sedikit kriminolog yang menyadari tradisi keadilan adat-- 
istilah keadilan restoratif tidak/belum muncul. Kemudian restorative justice baru muncul dalam tulisan-tulisan Colson dan Van Ness (1990), Mackey (1981, 1992), Van Ness dan Strong (1997), Wright (1991), dan Zehr (1985, 1990).11

Menurut Tony Marshall, restorative justice adalah sebagai berikut.

Restorative justice is a process whereby all the parties with a stake in a particular offence come together to resolve collectively how to deal with the aftermath of the offence and its implications for the future. ${ }^{12}$

Restorative justice (keadilan restoratif) merupakan suatu pendekatan keadilan yang memfokuskan kepada kebutuhan daripada para korban, pelaku kejahatan, dan juga melibatkan peran serta masyarakat, dan tidak semata-mata memenuhi ketentuan hukum atau semata-mata penjatuhan pidana. Dalam hal ini korban juga dilibatkan di dalam proses, sementara pelaku kejahatan juga didorong untuk mempertanggungjawabkan atas tindakannya, yaitu dengan memperbaiki kesalahan-kesalahan yang telah mereka perbuat dengan meminta maaf, membayar biaya pengobatan, atau dengan melakukan pelayanan masyarakat. ${ }^{13}$ Sehingga alur restorative justice memfokuskan pada kebutuhan pemulihan keadaan, baik dari sisi korban maupun pelaku kejahatan.

Sedangkan menurut Marlina, ${ }^{14}$ prinsip restorative justice ialah proses penyelesaian tindakan pelanggaran hukum yang

\footnotetext{
I Daly K. and R. Immarigeon, "The Past, Present, and Future of Restorative Justice: Some Critical Reflections.", The Contemporary Justice Review I, 1998, 24.

12 John Braithwaite, Restorative Justice \& Responsive Regulation, (Oxford University Press, New York, 2002), II.

${ }^{13}$ Djoko Prakoso. Kedudukan Justisiable di dalam KUHAP, (Jakarta: Ghalia Inonesia. 1986), 84.

14 Marlina, Peradilan Pidana Anak di Indonesia: Pengembangan Konsep Diversi dan Restorative Justice, Cetakan Pertama,(Bandung;Refika Aditana, 2009), 180.
} 
terjadi dilakukan dengan membawa korban dan pelaku (tersangka) bersama-sama duduk dalam satu pertemuan untuk bersama-sama berbicara.

Menurut Muladi, restorative justice adalah teori yang menekankan pada pemulihan kerugian yang disebabkan atau ditimbulkan oleh perbuatan pidana. Memulihkan kerugian ini akan tercapai dengan adanya proses-proses kooperatif yang mencakup semua pihak yang berkepentingan. ${ }^{15}$

Sedangkan menurut Chris Cunneen ${ }^{16}$, kriteria restorative justice yang ideal adalah sebagai berikut.

Certainly the ideal is that restorative justice will be beneficial for both victims and offenders. Victims will experience empowerment, healing, and closure. They will given the opportunity to ask questions about the offence and express their emotion. Offenders will confront the harm they have caused, take responsibility for their actions, apologize, act to repair the harm and as a result be accepted back into their community.

Restorative justice dapat dikatakan sebagai proses penyelesaian yang dilakukan di luar sistem peradilan pidana (criminal justice system) dengan melibatkan korban, pelaku, keluarga korban dan masyarakat serta pihak-pihak yang berkepentingan dengan suatu tindak pidana yang terjadi untuk mencapai kesepakatan dan penyelesaian. ${ }^{17}$

Dapat dikatakan bahwa konsep restorative justice merupakan sebuah terobosan hukum yang harus dan wajib digunakan dalam setiap perkara anak yang berkonflik dengan

15 Muladi, Kapita Selekta Hukum Pidana, (Semarang: Penerbit Universitas Diponegoro, 1995), 125.

16 Chris Cunneen and Carolyn Hoyle, Debating Restorative Justice, (United Kingdom Hart Publishing, , 20I0), 132.

17 Selamet Riadi, "Peran Penyidik Polri dalam Penerapan Diversi terhadap Anak Yang Berkonflik Dengan Hukum (Studi di PPA Polres Lombok Barat)", Jurnal IUS, Vol IV Nomor 2, Agustus 2016, 127. 
hukum..$^{18}$ Dalam Handbook on Restorative Justice Programmes yang diterbitkan oleh PBB disebutkan bahwa, "Restorative justice is an approach to problem solving that, in its various forms, involves the victim, the offender, their social networks, justice agencies and the community". 19

Pada konsep restorative justice, penanganan kejahatan yang terjadi bukan hanya menjadi tanggung jawab negara akan tetapi juga merupakan tanggung jawab masyarakat. Keterlibatan anggota masyarakat sangat dibutuhkan untuk membantu memperbaiki kesalahan dan penyimpangan yang terjadi di sekitar lingkungan masyarakat yang bersangkutan. Pemberian penghargaan dan penghormatan pada korban dengan mewajibkan pihak pelaku melakukan pemulihan kembali atau akibat tindak pidana yang telah dilakukannya. Pemulihan yang dilakukan oleh pelaku bisa berupa ganti rugi, pekerjaan sosial, melakukan sesuatu perbaikan atau kegiatan tertentu sesuai dengan keputusan bersama yang telah disepakati semua pihak dalam pertemuan yang dilakukan. ${ }^{20}$

Terkait prinsip keadilan restoratif menurut UndangUndang Nomor 11 Tahun 2012 Tentang Sistem Peradilan Pidana Anak menyebutkan bahwa:

penyelesaian perkara tindak pidana dengan melibatkan pelaku, korban, keluarga pelaku/korban dan pihak lain yang terkait untuk bersama-sama mencari penyelesaian yang adil dengan menekankan pemulihan kembali pada keadaan semula dan bukan pembalasan.

\footnotetext{
${ }^{18}$ Soepeno. Kriminalisasi Anak. Jakarta, 2010, 12

19 United Nations, Handbook on Restorative Justice Programmes, (New York: United Nations Publication, 2006), 6.

${ }^{20}$ Rio Fabry, "Analisis Penerapan Prinsip Restorative Justice dalam Perkara Tindak Pidana Lalu Lintas dengan Pelaku Anak", Tesis, (Lampung: Program Pascasarjana Magister IImu Hukum Fakultas Hukum Universitas Lampung, 2016), 27.
}

61 $\mid \begin{aligned} & \text { Al-Daulah } \\ & \text { Vol. 9, No.l, April } 2019\end{aligned}$ 
Adapun kerangka kerja keadilan restoratif bertumpu pada tiga prinsip dasar:

1. Fokus harus pada kerusakan yang dilakukan;

2. Kesalahan atau bahaya menghasilkan kewajiban; dan

3. Keterlibatan dan partisipasi oleh semua pihak..$^{21}$

Poros keadilan restoratif lebih menekankan aspek kemanusiaan dari kedua belah pihak, yaitu pelaku dan korban, dan perbaikan relasi sosial diantara keduanya, atau dengan kata lain, pemulihan pelaku-korban (victim-offender mediation) lebih penting daripada keadilan retributif. Melalui prinsip diversi, pendekatan restoratif lebih menekankan pada empati dari pelaku kepada korban, sebab empati adalah jembatan menuju pemulihan pelaku-korban. Yang tak kalah penting adalah kerelaan pengampunan oleh korban terhadap pelaku sebagai komponen penting dari proses pemulihan ini.

Tahap-tahapan yang biasanya dilakukan polisi dalam menerapkan prinsip keadilan restoratif terhadap tindak pidana ringan yang dilakukan oleh anak yaitu:

1. Memberi peringatan informal yakni dilakukan polisi dengan memberikan peringatan secara lisan terhadap anak dengan diberikan nasihat-nasihat kepada anak sebagai pelaku tindak pidana biasanya tindakan peringatan lisan ini dilakukan terhadap tindak pidana ringan seperti pengeroyokan dan perkelahian;

2. Memberi peringatan formal yakni berupa peringatan yang mewajibkan pihak pelaku membuat surat pernyataan tidak akan mengulangi perbuatannya, dan

\footnotetext{
${ }^{21}$ Katherine Beckett and Martina Kartman, Violence, Mass Incarceration and Restorative Justice: Promising Possibilities, (University of Washington, June 20, 20I6), 4.
} 
3. Pada tahap bersama-sama duduk mencari penyelesaian (keadilan restoratif) jika kesepakatan berhasil berdasarkan negosiasi biasanya dilakukan di atas surat perjanjian dan surat pernyataan. ${ }^{22}$

Adapun hambatan-hambatan dalam penerapan keadilan restoratif yang sering dialami oleh pihak berwajib adalah:

1. Pemahaman yang berbeda dalam penanganan anak berhadapan dengan hukum di antara korban dan aparat penegak hukum,

2. Belum ada persamaan persepsi antar aparat penegak hukum mengenai penanganan anak, dan

3. Pandangan masyarakat terhadap perbuatan tindak pidana masih cenderung merasa dendam dan ingin melakukan pembalasan terhadap pelaku kejahatan. ${ }^{23}$

Adapun kendala-kendala lainnya yang biasa ditemui antara lain ${ }^{24}$ :

1. Hambatan dari pihak keluarga korban

Pada banyak kasus tindak pidana anak dengan anak sebagai korban, pihak keluarga korban bersikeras menuntut agar pelaku anak diproses sesuai hukum. Mayoritas masyarakat terutama keluarga korban yang memandang bahwa anak yang berkonflik dengan hukum pun harus dihukum setimpal layaknya orang dewasa. Hal itu terjadi karena pihak keluarga korban tidak terima ketika anaknya terluka akibat tindakan kekerasan/penganiayaan yang dilakukan oleh pelaku. Hal itu menyulitkan penyidik dalam melakukan proses perdamaian terhadap kasus anak karena kuatnya pengaruh keluarga korban yang menentang proses diversi. Memang dalam proses diversi,

22 Kunti Widayati, "Penerapan Restorative Justice dalam Sistem Peradilan anak Berdasarkan Undang-Undang No. II Tahun 2002", Socioscientia: Jurnal IImu-IImu Sosial, September 2016, Volume 8 Nomor 2, 144.

23 lbid.,

${ }^{24}$ Anita Indah Setiyaningrum, "Diversi sebagai Bentuk Penyelesaian Perkara Pidana Anak Melalui Pendekatan Restorative Justice Oleh Penyidik Polda Jawa Tengah", Jurnal Hukum Khaira Ummah, Vol. 12 No. 4 Desember 2017, 978.

$\mathbf{6 3} \quad \begin{aligned} & \text { al-Daulah } \\ & \text { Vol. 9, No.1, April } 2019\end{aligned}$ 
faktor orang tua masing-masing pihak dapat menjadi masalah. Untuk itu, kepentingan orang tua tidak boleh mendominasi karena dapat menghambat efektivitas proses diversi.

2. Dalam proses diversi dapat menimbulkan modus pemerasan dari pihak korban

Dalam proses diversi pada intinya ingin mencapai kesepakatan damai antara pelaku dengan korban. Banyak kasus tindak pidana anak adalah penganiayaan/tindak kekerasan yang mengakibatkan korban menderita kerugian baik itu kerugian materi maupun luka fisik. Dalam beberapa kasus dalam proses diversi, pihak keluarga korban akan meminta ganti kerugian dalam jumlah besar. Tawar menawar ganti rugi ini dapat menghambat tercapainya kesepakatan diversi.

3. Keterbatasan kesediaan petugas Balai pemasyarakatan (Bapas) dan pekerja sosial

Minimnya tenaga di Balai Pemasyarakatan menjadi penghambat dalam penerapan diversi. Dalam Pasal 8 ayat (1) UU Sistem Peradilan Pidana Anak (SPPA) ditegaskan bahwa penyelesaian perkara pidana anak dengan cara musyawarah selain melibatkan Anak dan orang tua/walinya, korban dan/atau orang tua/walinya juga harus mengikutsertakan pembimbing kemasyarakatan, dan Pekerja Sosial Profesional.

4. Tidak tercapainya kesepakatan antara kedua pihak

Setelah dilakukan proses diversi yang melibatkan beberapa pihak untuk mencapai mufakat, ternyata tidak tercapai kesepakatan. Hal itu mengakibatkan proses diversi tidak berhasil.

Konsep mengenai restorative justice terdapat dalam Pasal 5 ayat (1) dan (2) Undang-Undang Republik Indonesia Nomor 11 Tahun 2012 tentang Sistem Peradilan Pidana Anak, yang 
menyatakan bahwa Sistem Peradilan Pidana Anak wajib mengutamakan pendekatan keadilan restoratif yang meliputi :

1. Penyidikan dan penuntutan pidana anak yang dilaksanakan sesuai dengan ketentuan peraturan perundang-undangan, kecuali ditentukan lain dalam undang-undang ini;

2. Persidangan anak yang dilakukan oleh pengadilan di lingkungan peradilan umum;

3. Pembinaan, pembimbingan, pengawasan, dan/atau pendampingan selama proses pelaksanaan pidana atau tindakan dan setelah menjalani pidana atau tindakan.

Keadilan restoratif dapat dikatakan mencakup beragam praktik informal yang dirancang untuk memulihkan korban, pelaku, dan masyarakat setelah tindak pidana terjadi. Dalam proses informal ini, memperbaiki kerusakan adalah tujuan utama, dan korban diberi kesempatan untuk mengatasi efek dari kejahatan yang ditengarai berpengaruh pada mereka. Selain untuk meminimalisir peran aktor negara, prinsip diversi juga untuk meningkatkan prinsip kekeluargaan dalam menangani kejahatan.

Tujuan utama dari restorative justice adalah perbaikan atau pergantian kerugian yang diderita oleh korban, pengakuan pelaku terhadap luka yang diderita oleh korban atau masyarakat akibat tindakannya, konsiliasi dan rekonsiliasi pelaku, korban dan masyarakat ${ }^{25}$.

Peradilan pidana dengan konsep restorative justice bertujuan untuk:

1. Mengupayakan perdamaian antara korban dan anak;

2. Mengutamakan penyelesaian di luar proses peradilan;

25 Prakoso Abintoro, Pembaruan Sistem Peradilan Pidana Anak, Surabaya: Laksbang Grafika, 2013), 161 .

$65 \mid \begin{aligned} & \text { Al-Daulat } \\ & \text { Vol. 9, No.1, April } 2019\end{aligned}$ 
3. Menjauhkan anak dari pengaruh negatif proses peradilan;

4. Menanamkan rasa tanggung jawab anak;

5. Mewujudkan kesejahteraan anak;

6. Menghindarkan anak dari perampasan kemerdekaan;

7. Mendorong masyarakat untuk berpartisipasi;

8. Meningkatkan keterampilan hidup anak.26

Restorative justice juga bertujuan merestorasi kesejahteraan masyarakat, memperbaiki diri dengan cara menghadapkan anak sebagai pelaku berupa pertanggungjawaban kepada korban atas tindakannya. Konsep restorative justice tidak akan berjalan secara efektif tanpa adanya kerjasama dan keterlibatan antara korban, pelaku, dan masyarakat.

Sebenarnya, prinsip restorative justice timbul karena minimnya kepuasan terhadap konsep keadilan dalam sistem peradilan pidana, sebab dalam proses peradilan pidana yang dilibatkan hanya pelaku dan negara sebagai pemegang hak memidana (ius puniendi), sedangkan prinsip keadilan perspektif korban kurang diperhatikan.

Penerapan prinsip keadilan restoratif mengutamakan alternatif terbaik bagi anak sebagai pelaku tindak pidana dengan tanpa mengesampingkan dan bahkan mengakomodir posisi korban. Pandangan keadilan restoratif juga memberikan kesempatan kepada korban untuk lebih terlibat secara aktif dalam proses penyelesaian perkaranya demi memenuhi rasa keadilannya.

Disamping itu, fungsi restoratif yang lebih mengedepankan pemulihan kembali pada kondisi semula terasa lebih humanis dalam praktiknya daripada pendekatan proses

${ }^{26}$ Nasir Djamil, Anak Bukan Untuk Di Hukum, (Jakarta: Sinar Grafika, 20 I3) , 133. 
peradilan anak dengan paradigma retributive justice yang berorientasi penghukuman yang mengakibatkan trauma tersendiri bagi anak tersebut.

Perlu diingat bahwa tujuan pemidanaan bagi anak tak semata penjatuhan sanksi bagi pelaku, namun yang lebih penting justru unsur pertanggungjawaban pelaku terhadap tindak pidana beserta penderitaan korban. Paradigma hukum ini mengingat kepentingan masa depan si anak dengan mengakomodir derita yang dialami oleh korban melalui proses pemulihan. Penyelesaian hukum ini perlu diprioritaskan untuk menghindari stigmatisasi sosial dan viktimisasi anak-anak yang harus ditanggungnya yang berdimensi seumur hidup. Beban psikis berlebih inilah yang coba dikurangi melalui pendekatan restorative justice.

Praktik dominan dalam keadilan restoratif dimulai dengan kepedulian terhadap korban dan kebutuhan pemulihan mereka. Ia berupaya memperbaiki kerusakan sebanyak mungkin yang diakibatkan tindak pidana, baik secara konkret dan simbolis. Oleh karena itu dalam pendekatan restoratif dikembangkan perlakuan untuk mengubah mindset pelaku tindak pidana. Prinsipnya, ia berusaha memperbaiki kegagalan sistem pengadilan untuk memenuhi kebutuhan restoratif pelaku dan dengan demikian mengurangi terjadinya pengulangan perilaku (residivis).

Usaha restoratif merupakan upaya pemulihan hubungan melalui reintegrasi orang-orang yang dirugikan dan mereka yang menyebabkan kerugian. Dikarenakan unsur kerugian-lah yang menjadi masalah utama dalam kerangka kerja restoratif, ia membutuhkan respons demi menghindari bahaya lebih lanjut. Dalam model restoratif, anak-anak pelaku teror tidak dipahami sebagai unsur potensial pelaku kriminal atau ancaman terhadap tatanan sosial. Sebaliknya, mereka diakui sebagai anggota

\footnotetext{
$67 \mid \begin{aligned} & \text { al-Daulah } \\ & \text { Vol. 9, No.1, April } 2019\end{aligned}$
} 
komunitas, dan komunitas itu bertanggung jawab atas mereka, sama seperti mereka yang memikul tanggung jawab atas pelanggaran yang dilakukan. Konsekuensinya, mereka diharuskan berkomitmen dan berjanji untuk memulihkan kembali kerusakan yang telah disebabkannya.

Oleh karena itu, keadilan restoratif membutuhkan usahausaha yang kooperatif dari komunitas dan pemerintah untuk menciptakan sebuah kondisi dimana pelaku dan korban dapat merekonsiliasi konflik diantara mereka dan memperbaiki lukaluka lama mereka. ${ }^{27}$

Yang perlu diingat, dalam praktiknya, proses restoratif mensyaratkan adanya pengakuan bersalah terlebih dahulu. Setelah adanya pengakuan bersalah dari pelaku tindak pidana, penyidik juga harus melihat motivasi dari pelaku melakukan tindak pidana terorisme, apakah pada dasarnya anak ini adalah jahat, ataukah karena faktor doktrinasi orang tua ataukah karena faktor pergaulannya.

Adapun mengenai penanganan terhadap anak pelaku tindak pidana terorisme harus lebih diprioritaskan pada pendekatan berorientasi pada pemulihan psikologis anak tersebut serta re-edukasi. berdasarkan data KPAI, terjadi peningkatan sebesar 3 persen pelanggaran terhadap anak pada tahun 2016 dibanding dengan tahun sebelumnya, yaitu dari 4.309 menjadi 4.482 kasus. Dari jumlah itu, anak yang menjadi korban radikalisme meningkat 42 persen dari 180 kasus menjadi 256 kasus. Hal ini penting untuk mengedukasi anak-anak yang terpapar terorisme agar kembali normal dan mempunyai masa depan yang baik. Dari data yang diperoleh BNPT, berdasarkan

${ }^{27}$ Dwidja Priyatno, Sistem Pelaksanaan Pidana Penjara di Indonesia, (Bandung: PT. Refika Aditama, 2006), 14-15. 
riset terhadap 110 pelaku tindakan terorisme, paling banyak ada di rentang usia 21-30 tahun (47,3 persen), setelah itu pada rentang usia 31-40 tahun (29,1 persen). Yang berusia di bawah 21 tahun ada 11,8 persen. Data ini berdasarkan penelitian pada tahun 2012.

Bagaimanapun, anak pelaku terorisme harus ditangani secara unik, yang berbeda dengan pelaku dewasa. Model anak yang diperlakukan sama dengan orang dewasa, melalui retributive justice amat tidak tepat. Disebabkan anak merupakan individu yang masih perlu berkembang dan berkreasi dalam semua aspek, Anak-anak yang dihukum hanya akan menyurutkan perkembangan mental dan pergaulan sosial di masa depannya.

Proses penghukuman yang diberikan kepada anak lewat sistem peradilan pidana formal dengan memasukkan anak ke dalam penjara dinilai tidak berhasil menjadikan anak jera dan menjadi pribadi yang lebih baik untuk menunjang proses tumbuh kembangnya. Penjara justru seringkali membuat anak semakin profesional dalam melakukan tindak kejahatan. ${ }^{28}$

Secara teoritis, pemenjaraan mengakibatkan anak mengalami proses dehumanisasi, bahaya kaderisasi di penjara dan labelisasi yang melekat sepanjang hayatnya. Pengurungan anak di lembagapemasyarakatan sangat berbahaya dan berdampak pada perkembangan sosialnya, biasanya menyusahkan baginya untuk cepat menyesuaikan diri dengan lingkungannya setelah ia meninggalkan lembaga pemasyarakatan.

Perlu disadari bahwa dalam proses peradilan pidana formal, seringkali hak-hak anak dikebiri mulai dari tahap penyidikan sampai ke tahap pelaksanaan putusan. Bagaimana tidak, mulai dari tahap penyidikan, aparat penegak hukum telah diberi wewenang oleh Undang-Undang untuk melakukan

${ }^{28}$ M. Joni \& Zulchaina Z. Tanamas, Aspek Hukum Perlindungan Anak,... I

69 \begin{tabular}{l|l} 
al-Daulah \\
Vol. 9, No.l, April 2019
\end{tabular} 
penahanan terhadap tersangka. Tentu saja kondisi ini menambah beban psikologis tertentu bagi si anak.

Prinsip ini penting diingat karena anak merupakan aset pembangunan sumber daya manusia (SDM) bangsa. Ia memerlukan pembinaan secara terus-menerus demi kelangsungan hidup pertumbuhan dan perkembangan fisik, mental dan sosial serta perlindungan dari segala kemungkinan yang membahayakan atau merusak masa depan anak ${ }^{29}$.

Oleh karena itu, menurut penulis, bandul paradigma hukum pidana dengan anak pelaku terorisme harus bergerak dari model retributif ke model restoratif, ada peluang nyata untuk menjaga dan memperkuat hak-hak anak. Dalam sistem peradilan pidana dengan anak sebagai pelakunya harus diupayakan melalui proses diversi, yaitu pengalihan penyelesaian perkara anak dari proses peradilan pidana ke proses di luar peradilan pidana.

Diversi bisa dikatakan sebagai pemberian kewenangan kepada aparat penegak hukum untuk mengambil tindakantindakan kebijaksanaan dalam menangani atau menyelesaikan masalah pelanggar anak dengan tidak mengambil jalan formal antara lain menghentikan atau tidak meneruskan/melepaskan dari proses peradilan pidana atau mengembalikan/menyerahkan kepada masyarakat dan bentuk-bentuk kegiatan pelayanan sosial lainnya. Penerapan diversi ini dilakukan di dalam semua tingkat pemeriksaan, dimaksudkan untuk mengurangi dampak negatif keterlibatan anak dalam proses peradilan tersebut. ${ }^{30}$

Jack E. Bynum menyatakan bahwa diversi adalah:

\footnotetext{
${ }^{29}$ Ediwarman, "Peradilan Anak di Persimpangan Jalan dalam Perspektif Victimologi (Belajar dari Kasus Raju)", Jurnal Mahkamah, Vol. 18 No. I, (Pekanbaru: Fakultas Hukum Universitas Lancakuning, 2006), 8.

30 Setya Wahyudi, Implementasi Ide Diversi dalam Pembaruan Sistem Peradilan Pidana Anak di Indonesia, (Yogyakarta: Genta Publishing, 20I I), 56.
} 
Diversion is an attempt to divert, or channel out, youthful offenders from the juvenile justice system. ${ }^{31}$

Menurut Romli Artasasmita, diversi berarti kemungkinan hakim menghentikan atau mengalihkan/tidak meneruskan pemeriksaan perkara dan pemeriksaan terhadap anak selama proses pemeriksaan di muka sidang. ${ }^{32}$

Sedangkan menurut Chris Graveson diversi adalah proses yang telah diakui secara internasional sebagai cara terbaik dan paling baik dalam menangani kasus anak yang berhadapan dengan hukum. Intervensi terhadap anak yang berhadapan dengan hukum sangat luas dan beragam, tetapi lebih banyak menekankan pada penahanan dan penghukuman, tanpa peduli betapa ringannya pelanggaran tersebut atau betapa mudanya usia anak tersebut. ${ }^{33}$

Diversi yang dimaksudkan untuk menghindari dan menjauhkan anak dari proses peradilan dan mengutamakan asas proporsionalitas dengan perlakuan hak atas anak secara memadai sesuai tingkat pemahaman anak, mengusahakan anak mempunyai rasa hormat pada pihak lain, sambil berusaha mengintegrasikan anak kembali di lingkungan masyarakatnya. ${ }^{34}$

Adapun dasar hukum pemberlakuan diversi bagi anak ialah ${ }^{35}$ :

1. Peraturan Internasional

a. Convenion on the Rights of The Child (Konvensi Hak-Hak Anak).

\footnotetext{
${ }^{31}$ Jack E. Bynum and Wiliam E. Thompson, Juvenile Delinquency a Sociological Approach, (Boston: Allyn and Bacon, 2002), 430.

32 Setya Wahyudi, Implementasi Ide Diversi , 14.

${ }^{33}$ Lilik Mulyadi, Wajah Sistem Peradilan Anak, (Bandung: Alumni, t.t.). I I I.

${ }^{34}$ Nandang Sambas, Pembaharuan Sistem Pemidanaan Anak di Indonesia, (Yogyakarta, Graha IImu, 20I0), 193.

35 Fiska Ananda, "Penerapan Diversi sebagai Upaya perlindungan Hukum Terhadap Anak Pelaku Tindak Pidana", Jurnal Daulat Hukum, Vol. I No. I Maret 20। 8, 80
} 
b. The United Nations Standard Minimum Rules for Administration of Juvenile Justice-the Beijing Rules (Peraturan Standar Minimum PBB untuk Pelaksanaan Peradilan Anak-Peraturan Beijing).

c. The United Nations Rules for the Protection of Juvenile Deprived of Their Liberty (Peraturan PBB untuk Perlindungan Anak yang Terampas kebebasannya)

2. Peraturan Nasional

a. Undang-Undang Republik Indonesia Nomor 2 Tahun 2002 tentang Polisi Republik Indonesia.

b. Undang-Undang Republik Indonesia Nomor 23 tahun 2002 tentang Perlindungan Anak.

c. Undang-Undang Republik Indonesia Nomor 3 Tahun 1997 Tentang Pengadilan Anak.

d. Undang-Undang Republik Indonesia Nomor 11 Tahun 2012 tentang Sistem Peradilan Anak.

e. TR Kabareskrim Nomor 1124/XI/2006 tentang Pedoman Pelaksanaan Diversi Bagi Kepolisian.

Proses penjatuhan pidana dianggap bukanlah solusi terbaik dalam menyelesaikan tindak pidana terorisme yang dilakukan oleh anak. Hal ini sesuai dengan tujuan dari pada peradilan pidana itu sendiri yakni agar terwujud peradilan pidana yang benar-benar menjamin perlindungan kepentingan terbaik terhadap anak.

United Nations Standard Minimum Rules for the Administration of Juvenile Justice (The Beijing Rules) telah memberikan pedoman sebagai upaya menghindari efek negatif tersebut. Yaitu dengan memberikan kewenangan kepada aparat penegak hukum mengambil tindakan-tindakan kebijakan dalam menangani atau menyelesaikan masalah pelanggar anak dengan 
tidak mengambil jalan formal, antara lain menghentikan atau tidak meneruskan atau melepaskan dari proses pengadilan atau mengembalikan/menyerahkan kepada masyarakat dan bentukbentuk kegiatan pelayanan sosial lainnya. Tindakan tersebut yang disebut diversi. ${ }^{36}$

Dapat dikatakan bahwa pelaksanaan pemidanaan yang sesungguhnya bagi anak pelaku terorisme dinilai belum tepat apabila masih dapat dicari jalan keluar lainnya. Diversi dilakukan untuk memberikan perlindungan dan rehabilitasi (protection and rehabilitation) kepada pelaku sebagai upaya untuk mencegah anak menjadi pelaku kriminal dewasa. ${ }^{37}$ Tujuan secara umum sistem diversi antara lain ${ }^{38}$ :

1. Tercapainya perdamaian antara korban dan anak;

2. Penyelesaian perkara anak di luar proses peradilan;

3. Menghindarkan anak dari perampasan kemerdekaan;

4. Mendorong masyarakat untuk berpartisipasi;

5. Menanamkan rasa tanggungjawab pada anak.

Sementara dalam Pasal 8 Undang-Undang Sistem Peradilan Pidana Anak diterangkan bahwa sistem diversi wajib memperhatikan:

1. Kepentingan korban;

2. Kesejahteraan dan tanggung jawab anak;

3. Penghindaran pembalasan;

4. Keharmonisasian masyarakat; dan

5. Kepatutan, kesusilaan, dan ketertiban umum.

Fungsi utama sistem diversi adalah mencegah anak dari pengaruh kriminalitas di dalam penjara. Upaya inilah yang di

\footnotetext{
${ }^{36}$ Setya Wahyudi, Implementasi Ide Diversi , 4.

37 Ibid., 77.

38 Yutirsa Yunus, "Analisis Konsep Restorative Justice mellaui Sistem Diversi dalam Slstem Peradilan Pidana Anak di Indonesia", Jurnal Rechtsvinding: Media Pembinaan Hukum Nasional, Volume 2 No. 2 Agustus 2013, 24l.
} 
Amerika Serikat dikenal dengan istilah deinstitusionalisation system peradilan pidana formal. ${ }^{39}$ Konsep diversi ini paling banyak diterapkan pada kasus tindak pidana yang dilakukan anak dan remaja di New Zealand, Wales, Inggris, Kanada dan Filipina. ${ }^{40}$

Dengan diversi, perlindungan atas hak-hak anak yang bermasalah dengan hukum dapat lebih terjamin serta dapat menghindarkan anak dari stigma negatif sebagai "anak nakal" karena tindak pidana melibatkan anak sebagai pelaku dapat ditangani tanpa perlu melalui proses hukum formal yang ada. ${ }^{41}$

Untuk itu, menurut penulis, pelaksanaan proses pemidanaan melalui jalur litigasi bagi anak pelaku tindak pidana terorisme akan banyak madharat-nya ketimbang manfaatnya. Hal ini sesuai dengan yang tertuang dalam United Nations Standard Minimum Rules for the Administration of Juvenile Justice (The Beijing Rules) butir 6 dan 11 yang menyatakan sebagai berikut;

6. Scope of Direction

6.1 In view of the varying special needs of juveniles as well as the variety of measures available, appropriate scope for discretion shall be allowed at all stages of proceedings and at the different levels of juvenile justice administration, including investigation, prosecution, adjudication and the follow-up of dispositions.

\section{Diversion}

11.1 Consideration shall be given, wherever appropriate, to dealing with juvenile offenders without resorting to formal trial by the competent authority, referred to in rule 14.1 below.

11.2 The police, the prosecution or other agencies dealing with juvenile cases shall be empowered to dispose of such cases, at their discretion, without recourse to formal hearings, in

\footnotetext{
39 Marlina, "Penerapan Konsep Diversi Terhadap Anak Pelaku Tindak Pidana dalam Sistem Peradilan Pidana Anak", Jurnal Equality, Vol. 13 No. I 2008, 97.

40 Yutirsa Yunus, "Analisis Konsep Restorative Justice..." , 237.

${ }^{41}$ Ibid., 79
} 
accordance with the criteria laid down for that purpose in the respective legal system and also in accordance with the principles contained in these Rules.

Yang perlu dicatat, proses pengalihan hukum (diversi) tidak akan berjalan apabila tidak menggunakan restorative justice sebagai penyelesaiannya. Pengalihan hukum (diversi) melalui pendekatan restorative justice dapat diterapkan pada tahap pemeriksaan di sidang pengadilan. Menurut Pasal 52 ayat (2) Undang-Undang Sistem Peradilan Pidana Anak menjelaskan "Hakim wajib mengupayakan diversi paling lama tujuh hari setelah ditetapkan oleh ketua pengadilan negeri sebagai hakim". Apabila proses pengalihan hukum (diversi) melalui pendekatan restorative justice berhasil mencapai kesepakatan, hakim menyampaikan berita acara diversi kepada ketua pengadilan negeri untuk dibuat penetapan. Apabila diversi gagal maka perkara tersebut dilanjutkan ke tahap persidangan dengan menjaga suasana kekeluargaan tetap terjaga, sehingga anak dapat mengutarakan segala peristiwa dan perasaanya secara terbuka dan jujur selama sidang berjalan. ${ }^{42}$

Menurut UU No. 11 Tahun 2012 tentang Sistem Peradilan Pidana Anak, penerapan diversi/mediasi berdasarkan restorative justice bisa diterapkan pada tahap penyidikan, penuntutan, dan pengadilan. Diversi menyediakan seperangkat sistem yang memberikan kesempatan lebih baik bagi anak pelaku kejahatan terorisme, sebagai bentuk pengalihan atau penyimpangan kenakalan anak dari proses peradilan formal ke arah penanganan anak yang lebih bersifat pelayanan kemasyarakatan.

Adapun beberapa bentuk-bentuk diversi adalah sebagai berikut ${ }^{43}$ :

\footnotetext{
${ }^{42}$ Nasir Djamil, Anak Bukan Untuk Di Hukum , 163.

${ }^{43}$ Lilik Mulyadi, Wajah Sistem Peradilan Anak, IIII.

75 \begin{tabular}{l|l} 
al-Daulat \\
Vol. 9, No.l, April 2019
\end{tabular}
} 
1. Non intervensi

2. Peringatan informal

3. Peringatan formal

4. Mengganti kesalahan dengan kebaikan/restitusi

5. Pelayanan masyarakat

Secara umum, syarat-syarat dilakukan ide diversi dalam perkara anak, yaitu:

1. Pelaku anak yang baru pertama kali melakukan tindak pidana;

2. Umur anak relatif masih muda;

3. Implementasi bentuk program-program diversi yang dikenakan pada anak mendapat persetujuan pada orang tua atau wali, maupun anak yang bersangkutan;

4. Kejahatan yang dilakukan dapat tindak pidana yang ringan ataupun yang berat (dalam kasus tertentu);

5. Anak telah mengaku bersalah melakukan tindak pidana/kejahatan;

6. Masyarakat mendukung dan tidak keberatan, atas pengalihan pemeriksaan ini.

Jika pelaksanaan program diversi gagal, maka pelaku anak tersebut dikembalikan untuk diperiksa secara formal. ${ }^{44}$

Melalui sistem diversi, anak akan terhindar dari penerapan hukum pidana yang dalam ditengarai sebagai salah satu faktor kriminogen, berarti juga menghindarkan anak dari kemungkinan menjadi jahat kembali (residive). Selain itu, anak tetap dapat berkomunikasi dengan lingkungan asalnya sehingga tidak perlu beradaptasi lagi pasca tindak kejahatannya serta anak terhindar dari dampak negatif prisionisasi yang seringkali

\footnotetext{
${ }^{44}$ Aras Firdaus, "Perlindungan Hukum bagi Anak..." 9- 10.
} 
merupakan sarana kaderisasi tindak pidana. Akibatnya, terjadi proses pemulihan kembali secara psikis dan sosial antara pelaku, korban, dan masyarakat pada kondisi semula, dengan mengurangi resiko adanya tindak saling balas.

Dalam sistem diversi, pihak-pihak terkait dipertemukan untuk mencari penyelesaian terhadap masalah yang diakibatkan tindak pidana yang terjadi dengan hasil akhir anak tersebut tidak dikenakan hukuman pemidanaan, melainkan harus menjalani kesepakatan yang ditetapkan diversi tersebut. Penerapan diversi pada tindak pidana anak memberikan peluang besar untuk menjauhkan anak dari proses peradilan yang tidak diperlukan demi menjaga jiwa, moral, dan masa depan anak tersebut.

Dapat disimpulkan bahwa pemberlakuan sistem diversi didasarkan untuk menghindari stigmatisasi negatif yang diakibatkan oleh proses pengadilan terhadap anak hingga akan lebih baik mengalihkannya pada proses non-litigasi. ${ }^{45}$ Pendeknya, penerapan diversi dimaksudkan agar anak terhindar dari sistem peradilan pidana yang berujung pada pemidanaan anak tersebut.

Prinsip kerjanya, pelaksanaan diversi bertujuan meminimalkan pelaksanaan proses pidana yang berbasis litigasi dengan dialihkan pada jalur non-litigasi agar pihak pelaku dan korban dapat menikmati keadilan demi kepentingan masa depan bagi kedua belah pihak. Hal ini menjadi prinsip alasan dilakukan diversi khususnya bagi tindak pidana anak, untuk mewujudkan kesejahteraan bagi anak itu sendiri. Melalui diversi dapat memberikan kesempatan bagi anak pelaku teror untuk menjadi

45 Randall G. Shelden, Detention Diversion Advocacy; an Evaluation, (Washington DC: U.S.:Department of Justice, 1997), I. 
sosok baru yang bersih dari catatan kejahatan dan tidak menjadi residivis. ${ }^{46}$

\section{Model Diversi Melalui Restorative Justice Pada Anak Pelaku Tindak Pidana Terorisme}

Pada dasarnya, proses pengalihan hukum (diversi) tidak akan berjalan sebagaimana mestinya apabila tidak menggunakan pendekatan restorative justice sebagai penyelesaiannya. Namun sayangnya proses diversi melalui pendekatan restorative justice hanya dapat digunakan pada kasus anak yang ancaman pidananya di bawah 7 (tujuh) tahun dan bukan merupakan pengulangan, sebagaimana termaktub dalam Pasal 7 ayat (2) Undang-Undang Nomor 11 Tahun 2012 Tentang Sistem Peradilan Pidana Anak.

Ketentuan ini tentu saja mengerdilkan faktor kemanusiaan dan empati dalam proses penjatuhan hukuman pada anak pelaku terorisme. Disebabkan walaupun posisi hukumnya sebagai pelaku, namun pada hakikatnya anak pelaku terorisme adalah korban indoktrinasi dari faktor luar, utamanya dari orang tuanya. Tak hanya itu, bahaya isolasi sosial dan publisitas negatif terhadap anak dapat menimbulkan tumpukan beban psikis tersendiri baginya. Dengan demikian, diversi dapat mengurangi kemungkinan pelaku anak untuk menjadi residivis di masa depan.

Padahal Dunkel menyebutkan, setidaknya, ada enam alasan pendukung sekaligus membenarkan praktik diversi:

1. Mencegah stigmatisasi negatif;

2. Mempromosikan tindakan edukatif bukannya hukuman;

3. Menghindari hukuman yang tidak proporsional;

4. Mengurangi (atau membatasi) beban kasus pengadilan;

${ }^{46}$ Marlina, Pengantar Konsep Diversi dan Restroative Justice Dalam Hukum Pidana, (t.tp.:USU Press, , 2010), 22. 
5. Mengurangi intervensi negara dalam kenakalan remaja;

6. Keuntungan hukuman yang lebih ringan. ${ }^{47}$

Bahkan The Beijing Rules secara eksplisit menyebutkan bahwa pengalihan seharusnya tidak terbatas pada kasus-kasus kecil ${ }^{48}$. Oleh karena itu, secara teoritis, sistem diversi memberikan kemungkinan untuk menerapkan pengalihan dalam pelanggaran utama seperti pembunuhan, pemerkosaan, atau pelecehan seksual, bahkan terorisme. Adapun mengingat usia si anak, logika hukumnya, semakin muda usia si anak pelaku teror, maka semakin tinggi kemungkinan untuk diterapkan proses diversi tersebut.

Perlu diingat, catatan kriminal dan stereotype sebagai teroris memiliki efek yang sangat panjang dan luas bagi seorang anak. Anak-anak juga cenderung menderita jangka panjang konsekuensi dari memiliki catatan kriminal. Ini mempengaruhi penampilan mereka di masa depan, meliputi pekerjaan, mendapatkan visa, asuransi, pinjaman kredit, SKKB kepolisian. Artinya, masa depannya akan terenggut hanya karena diposisikan sebagai pelaku teroris, yang tak mustahil padahal ia adalah korban dalam arti sesungguhnya.

Sebagai korban "kejahatan" indoktrinasi orang tua, anak "pelaku" teroris berhak mendapatkan hak yang adil dan pemulihan efektif. Hingga memberi hak kepada anak pelaku teroris butuh pemulihan fisik dan psikologis, reintegrasi dan rehabilitasi sosial yang dapat memulihkan harga diri dan martabat anak. Oleh karena itu diperlukan prosedur informal yang cepat, adil, murah, dan mudah diakses sangat penting dalam memperkuat akses anak untuk memperoleh ganti rugi. Sedangkan kondisi anak-anak memiliki kekurangan pemahaman tentang

\footnotetext{
47 Debby Naztty Pratiwi, "Balancing The Interests of Child Offenders and Child Victims through Diversion in Child-on-Child Crime: Evaluation through The International Children's Rights Legal Framework (In The Context of Indonesia Juvenile Justice System)", Thesis, (t.tp.:Leiden University Faculty of Law, 2017-2018), 6.

${ }^{48}$ Pasal II ayat 3 The Beijing Rules.
} 
sistem peradilan pidana, terkait prosedur, dan hak yang mereka punya.

Penerapan diversi melalui restorative justice dapat mengeksplorasi interkoneksi antara pengalihan dan pemulihan keadilan yang lebih bersifat alamiah tanpa melalui akses ke proses peradilan. Diversi dapat digunakan untuk mencapai keadilan restoratif dan, pada saat yang sama, sebagai alat untuk mengakses keadilan.

Proses diversi berarti proses antara korban dan pelaku dan jika perlu individu lain atau anggota masyarakat yang terkena dampak kejahatan, berpartisipasi bersama secara aktif dalam penyelesaian masalah yang timbul dari kejahatan, umumnya dengan bantuan seorang fasilitator yang mengarah pada persetujuan. Dalam praktik diversi di Indonesia, otoritas negara diwakili oleh otoritas; polisi, jaksa, hakim dan petugas pada masa percobaan. Sebagai fasilitator, mereka perlu mendengar kedua belah pihak selama pertemuan.

Diversi menghindari efek potensial dari label kenakalan formal yang dapat memengaruhi citra dirinya dan berkontribusi pada perilaku nakal berikutnya. Selain itu, keuntungan lainnya ialah mengurangi beban tunggakan kasus di pengadilan dan ongkosnya lebih sederhana dan berbiaya murah.

Diversi berperan sebagai alat untuk mencapai tujuan yang lebih signifikan dari keadilan restoratif. Ia juga memiliki pendekatan yang lebih pedagogis yang lebih disukai bagi anak pelaku teroris dan juga dapat bermanfaat baginya sampai batas tertentu.

Sebaliknya, dalam proses pidana formal, anak-anak harus melalui suatu proses yang asing, mereka bertemu dengan banyak petugas di berbagai tahap proses, mereka sering merasa terintimidasi dan ketakutan, dan mereka memiliki pengetahuan yang terbatas tentang tata cara proses hukum bekerja. Intinya, anak mengalami efek samping persidangan formal. Entah hukuman bagi pelaku akan diakhiri dengan vonis bebas atau 
terbukti bersalah, namun treatment ini dapat menyebabkan beban emosional yang signifikan pada anak tersebut.

Pendekatan diversi melalui restorative justice memberikan kemungkinan bagi pihak berwajib terhadap anak pelaku teror untuk berkomunikasi dengannya, menemukan motif di balik kejahatannya, dan mengupayakan rasionalisasi deradikalisasi yang dapat menyembuhkan mindset teror mereka. Hal ini tergolong amat penting untuk memutus rantai radikalisasi dan kaderisasi pelaku teror yang melibatkan anak-anak. Aspek lain yang tak kalah penting adalah -melalui diversi-, negara turut mempromosikan langkah-langkah edukatif untuk proses reintegrasi sosial yang lebih baik bagi masyarakat. Artinya, proses ini membantu menghubungkan kembali dia dengan komunitasnya.

Selain itu, diversi membantu anak pelaku teror untuk belajar dari kesalahan mereka melalui intervensi awal, memberikan pemulihan trauma bagi para korban dan keluarga, memungkinkan anak-anak untuk bertanggung jawab atas tindakan mereka. Hal ini sesuai dengan paradigma UndangUndang Nomor 11 Tahun 2012 Tentang Sistem Peradilan Pidana Anak bahwa perlakuan hukum kepada anak-anak harus diperlakukan secara berbeda dari orang dewasa karena secara filosofis, anak merupakan amanah dan karunia Tuhan Yang Maha Esa yang memiliki harkat dan martabat sebagai manusia seutuhnya.

\section{Perspektif Maqāshid Syarī'ah}

\section{Perlindungan Agama}

Agama Islam menjaga hak paling asasi, yaitu kebebasan berkeyakinan dan beribadah. Setiap pemeluk agama berhak atas agama dan mazhab lainnya, dan juga tidak boleh ditekan untuk berpindah dari keyakinanannya untuk masuk Islam.

Melalui pendekatan diversi, anak pelaku teror harus dilakukan upaya pembinaan dan deradikalisasi demi menjaga keyakinan keberagamaannya agar tidak menyimpang. Bukan 
sebaliknya, hanya bertujuan untuk menangkap dan menghukumnya saja. Sebab pendekatan retributive hanya akan menciptakan labelisasi serta menumbuhkan bara dendam terhadap aparat.

Pembinaan spiritual yang dimaksud tentu harus melalui pendekatan dialogis, bukan konfrontatif. Disebabkan pada dasarnya mereka adalah kader penerus bangsa yang semangat keagamaannya tinggi namun tidak didukung oleh pemahaman keagamaan yang tepat.

Selain itu, anak-anak tersebut perlu dilibatkan secara aktif dalam kegiatan-kegiatan sosial-keagamaan agar mereka tidak merasa dikucilkan secara sosial. Kongkretnya, misalnya dilibatkan dalam seminar-seminar yang mengangkat tema toleransi beragama agar mereka tak hanya tahu tetapi juga memahami bahwa umat beragama lain tak sesuai dengan penggambaran mindset mereka sebelumnya. Tujuannya, agar mereka dapat menjalin hubungan persaudaraan dengan kaum non-muslim sebagai sesama warga kemanusiaan. Tak cukup itu, jalinan toleransi keberagamaan di Indonesia merupakan realitas yang niscaya di tengah kemajemukan bangsa.

2. Perlindungan Jiwa

Sebagaimana diuraikan di atas bahwa dalam restorative justice dipersyaratkan bahwa pelaku kejahatan harus menyadari kejahatan yang diperbuat berikut dampaknya untuk mempertanggungjawabkan tindakannya, yaitu dengan memperbaiki kesalahan-kesalahan yang telah mereka perbuat dengan tujuan meminta maaf kepada korban dan keluarganya. Melalui pendekatan restorative justice dengan model diversi, anak pelaku teror akan menyadari bahwa doktrin bunuh diri dengan menggunakan bom ataupun melukai diri sendiri dengan tujuan berkorban demi agama (jihād fì sabìlillah) ternyata tidak sesuai dengan pemahaman mereka selama ini. Ajaran Islam sangat menghargai nyawa seseorang hingga adanya larangan 
membunuh, bahkan pelaku pembunuhan diancam dengan hukuman qisas (Q.S. Al-Baqarah ayat 178-179).

Bahkan dalam ayat lain pun diterangkan bahwa barangsiapa yang membunuh seorang manusia, bukan karena orang itu (membunuh) orang lain, atau bukan karena membuat kerusakan di muka bumi, maka seakan-akan dia telah membunuh manusia seluruhnya. Dan barangsiapa yang memelihara kehidupan seorang manusia, maka seolaholah dia telah memelihara kehidupan manusia semuanya (QS. AlMaidah: 32).

3. Perlindungan Akal

Islam sangat memperhatikan fungsi akal agar manusia bisa mendayagunakannya secara optimal. Untuk itu, Islam mengharamkan pelaku minuman keras (khamr) demi memelihara fungsi akal (Q.S. Al-Maidah ayat 90-91).

Melalui upaya restorative justice dengan pendekatan diversi, mindset anak pelaku teror yang semula teracuni dengan doktrin kebencian akan ternetralisir melalui upaya deradikalisasi. Selain itu, ia dapat melanjutkan pendidikannya tanpa harus mengkhawatirkan stigmatisasi negatif sebagai pelaku teror ataupun keluarga teroris. Sebab bila hanya menggunakan pendekatan punishment (retributif), anak pelaku teror hanya akan mendekam dalam penjara dengan stereotype teroris yang akan melekat seumur hidup dengan tanpa bisa meneruskan sekolahnya. 4. Perlindungan Harta

Islam memandang harta sebagai sarana bagi manusia untuk lebih mendekatkan diri kepada Allah. Dengan harta, manusia diharapkan mengembangkan sikap filantropi yang memperkuat esensi kemanusiaannya. Untuk itulah diajarkan zakat, sedekah, hibah, infak, serta pelarangan memakan harta orang lain yang bukan haknya (Q.S. 4: 29). Tak hanya itu, Islam juga melarang praktik riba untuk melindungi konsumen agar terhindar dari tindakan zalim (Q.S. 2: 275, dan Q.S. 2: 278). Tindak kriminal pencurian pun diancam dengan sanksi pemotongan tangan sebagai simbolisasi efek jera agar tidak mengulangi perbuatannya lagi (Q.S. 5: 38). 
Dengan restorative justice melalui model diversi, anak pelaku teror terhindar dari stigmatisasi negatif dari masyarakat sehingga ia dapat melanjutkan hidup dengan mencari pekerjaan yang layak bagi kemanusiaan. Ia tak perlu khawatir dengan proses peradilan yang begitu represif. Anak juga cenderung tak perlu menderita jangka panjang sebagai konsekuensi dari catatan kriminalnya. Ini sangat berpengaruh dalam masa depannya, meliputi mencari pekerjaan, mendapatkan visa, pinjaman kredit, dan SKKB Kepolisian.

\section{Perlindungan Keturunan}

Demi menjaga eksistensi kemanusiaan, Islam mengatur tentang anjuran menikah dan pelarangan perzinaan (Q.S. al-Isra' ayat 32). Rasulullah saw. bersabda, menikahlah, karena sesungguhnya aku akan membangga-banggakan jumlah kalian kepada umat-umat lain (H.R. Baihaqi). Sedang dalam hadis lain dijelaskan, wahai para pemuda, barangsiapa di antara kalian yang mampu menikah, maka menikahlah, karena menikah lebih dapat menahan pandangan dan lebih memelihara kemaluan, dan barangsiapa yang tidak mampu, maka hendaklah ia berpuasa; sebab puasa dapat menekan syahwatnya.

Dalam penanganan terhadap anak pelaku teror dengan pendekatan restorative justive model diversi, akan terhindar upaya penghukuman mati bagi si pelaku yang di bawah umur. Konsekuensinya, ia dapat terus melanjutkan hidupnya, tumbuhkembang serta meneruskan keturunanannya. Pendekatan hukum ini dapat menjamin pertumbuhan dan perkembangan anak dengan wajar, baik secara rohani, jasmani maupun sosial.

Hal ini sesuai dengan bunyi Pasal 28 ayat (2) UndangUndang Dasar Tahun 1945 menyatakan bahwa setiap anak berhak atas kelangsungan hidup, tumbuh dan kembang, serta berhak atas perlindungan dan diskriminasi. Di Pasal 28B ayat 1 juga disebutkan bahwa setiap orang berhak membentuk keluarga dan melanjutkan keturunan melalui perkawinan yang sah. Hal ini diuraikan pula dalam Undang-Undang Republik Indonesia Nomor 
39 Tahun 1999 tentang Hak Asasi Manusia dan Undang-Undang Republik Indonesia Nomor 23 Tahun 2002 tentang Perlindungan Anak.

\section{Penutup}

Penerapan sanksi pidana formil bagi anak pelaku teror amatlah tidak tepat sehingga perlu ditinjau ulang. Hal ini karena sanksi pidana formil mengandung lebih banyak aspek-aspek negatif daripada aspek-aspek positifnya, terlebih bagi anak-anak. Efek negatifnya, anak akan mengalami dehumanisasi karena ia tak bisa melanjutkan hidupnya secara wajar. Stigmatisasi akan melekat padanya sepanjang hidup. Disamping itu, pola pemenjaraan telah tumbuh menjadi tempat kaderisasi pelaku kriminal.

Sementara pendekatan restorative justice dengan model diversi, pelaku didorong untuk memperbaiki kerugian yang telah ditimbulkannya dan memulihkan kondisinya dengan melibatkan secara aktif korban, keluarganya dan juga masyarakat. Pendekatan hukum inilah yang disebut Karel Menninger ${ }^{49}$ sebagai pergeseran dari "sikap memidana" (punitive attitude) ke arah "sikap mengobati" (therapeutic attitude). Jika dalam paradigma retributif, sanksi pidana menyasar pada perbuatan pelaku lewat pengenaan hukuman agar pelaku menjadi jera. Sebaliknya, upaya diversi bertujuan pada upaya memberi pertolongan agar dia berubah. Sehingga, model restorative justice bertujuan lebih bersifat mendidik dan lebih berorientasi pada perlindungan masyarakat.

Pendekatan restorative justice melalui diversi pada anak pelaku teror lebih diarahkan kepada reparasi, restorasi atas kerusakan, kerugian yang diderita akibat kejahatan dan memprakarsai serta memfasilitasi pemulihan kondisi. Melalui restorative justice dengan model diversi, dampak kejahatan akan dimitigasi bahkan tereliminir, dan menawarkan pendekatan yang lebih kontekstual terhadap konsep hukuman. Dalam praktiknya,

${ }^{49}$ Stanley Grupp E., Theories of Punishment, (London: Indiana University Press, 1971,) 250.

85 \begin{tabular}{l|l} 
al-Daulah \\
Vol. 9, No.l, April 2019
\end{tabular} 
pendekatan restorative justice dengan model diversi pada anak pelaku teror selaras dengan tujuan syariah (maqāshid al-syarī'ah). Dikarenakan dalam operasionalisasinya, nilai-nilai operatif menjaga agama, jiwa, akal, harta, dan keturunan dapat terealisasi secara lugas dengan pendekatan yang lebih humanis daripada menggunakan paradigma retributive serta pendekatan hukum ini bermanfaat pula untuk mengurangi populasi lembaga pemasyarakatan yang over capacity.

\section{Daftar Pustaka}

Abintoro. Prakoso. Pembaruan Sistem Peradilan Pidana Anak. Surabaya: Laksbang Grafika, 2013.

Ananda. Fiska. "Penerapan Diversi sebagai Upaya Perlindungan Hukum Terhadap Anak Pelaku Tindak Pidana". Jurnal Daulat Hukum. Vol. 1 No. 1 Maret 2018.

Braithwaite. John. Restorative Justice \& Responsive Regulation. New York: Oxford University Press, 2002.

Danielt. Reyner Timothy. Penerapan Restorative Justice Terhadap Tindak Pidana Pencurian di Bawah Umur, Lex et Societas, Vol. II, No.6/ Juli 2014.

Dellyana. Shanty. Wanita Dan Anak Di Mata Hukum. Yogyakarta: Liberty, 1988.

Djamil. Nasir. Anak Bukan Untuk Di Hukum. Jakarta: Sinar Grafika, 2013.

E.. Stanley Grupp. Theories of Punishment. London: Indiana University Press, 1971.

Ediwarman. Peradilan Anak di Persimpangan Jalan dalam Perspektif Victimologi (Belajar dari Kasus Raju). Jurnal

Mahkamah Vol. 18 No. 1, Fakultas Hukum Universitas Lancakuning. Pekanbaru: 2006.

Fabry. Rio. "Analisis Penerapan Prinsip Restorative Justice dalam Perkara Tindak Pidana Lalu Lintas dengan Pelaku Anak". 
Tesis Program Pascasarjana Magister. Lampung: Ilmu Hukum Fakultas Hukum Universitas Lampung, 2016.

Firdaus. Aras. "Perlindungan Hukum bagi Anak Pelaku Tindak

Pidana Kejahatan Seksual Melalui Diversi dalam Sistem

Peradilan Anak (Juvenile justice System)", USU Law Journal, Vol. 4, No. 3, Juni 2016.

Gultom. Maidin. Perlindungan Hukum Terhadap Anak dalam Sistem

Peradilan Pidana Anak di Indonesia. Bandung: Refika Aditama, 2014.

Hoyle. Chris Cunneen and Carolyn. Debating Restorative Justice.

United Kingdom: Hart Publishing, 2010.

Human Rights Watch. Children Behind Bars. The Global Overuse of Detention of Children, https://www.hrw.org/worldreport/2016/children-behind-bars.

Immarigeon. Daly K. and R.. "The Past, Present, and Future of Restorative Justice: Some Critical Reflections.", The Contemporary Justice Review 1, 1998.

Kartman. Katherine Beckett and Martina. Violence, Mass Incarceration and Restorative Justice: Promising Possibilities, University of Washington: June 20, 2016.

Marlina. "Penerapan Konsep Diversi Terhadap Anak Pelaku Tindak Pidana dalam Sistem Peradilan Pidana Anak". Jurnal Equality, Vol. 13 No. 12008. . Peradilan Pidana Anak di Indonesia: Pengembangan Konsep

Diversi dan Restorative Justice. Cet. 1. Bandung: Refika Aditama, 2009. . Pengantar Konsep Diversi dan Restroative Justice Dalam Hukum Pidana. Cet. 1. USU Press: 2010.

Muladi. Kapita Selekta Hukum Pidana. Semarang: Penerbit Universitas Diponegoro, 1995.

Mulyadi. Lilik. Wajah Sistem Peradilan Anak, Bandung: Alumni, 2014.

Prakoso. Djoko. Kedudukan Justisiable di dalam KUHAP. Jakarta: Ghalia Inonesia. 1986. 
Pratiwi. Debby Naztty. "Balancing The Interests of Child Offenders and Child Victims through Diversion in Child-onChild Crime: Evaluation through The International Children's Rights Legal Framework (In The Context of Indonesia Juvenile Justice System)". Thesis. Leiden: University Faculty of Law, 2017-2018.

Priyatno. Dwidja. Sistem Pelaksanaan Pidana Penjara di Indonesia. Bandung: PT. Refika Aditama, 2006.

. Wajah Hukum Pidana Asas dan Perkembangan.

Bekasi: Gramata Publishing, 2012.

Riadi. Selamet. "Peran Penyidik Polri dalam Penerapan Diversi terhadap Anak Yang Berkonflik Dengan Hukum (Studi di PPA Polres Lombok Barat)". Jurnal IUS, Vol IV Nomor 2, Agustus 2016.

Sambas. Nandang. Pembaharuan Sistem Pemidanaan Anak di Indonesia. Yogyakarta: Graha Ilmu, 2010.

Setiyaningrum. Anita Indah. “Diversi sebagai Bentuk Penyelesaian Perkara Pidana Anak Melalui Pendekatan Restorative Justice Oleh Penyidik Polda Jawa Tengah". Jurnal Hukum Khaira Ummah, Vol. 12 no. 4 Desember 2017.

Shelden. Randall G.. Detention Diversion Advocacy; an Evaluation. Washington DC: U.S. Department of Justice, 1997.

Soepeno. Kriminalisasi Anak. Jakarta, 2010.

Tanamas. M. Joni \& Zulchaina Z.. Aspek Hukum Perlindungan Anak

Dalam Perspektif Konvensi Hak Anak. Bandung: Citra Aditya Bakti, 1999.

Thompson. Jack E. Bynum and Wiliam E.. Juvenile Delinquency a Sociological Approach, Boston: Allyn and Bacon, 2002.

UNICEF. Child Protection Information Sheet. Child Protection Information Sheet, 2006.

United Nations. Handbook on Restorative Justice Programmes. New York: United Nations Publication, 2006. 
Wahyudi. Setya. Implementasi Ide Diversi dalam Pembaruan Sistem Peradilan Pidana Anak di Indonesia. Yogyakarta: Genta Publishing, 2011.

Wicaksono. Adi Hardiyanto. "Kebijakan Pelaksanaan Diversi Sebagai Perlindungan Bagi Anak Yang Berkonflik dengan Hukum Pada Tingkat Penuntutan Di Kejaksaan Negeri Kudus". Jurnal Law Reform, Volume 11 Nomor 1 Tahun 2015. Widayati. Kunti. "Penerapan Restorative Justice dalam Sistem Peradilan anak Berdasarkan Undang-Undang No. 11 Tahun 2002". Socioscientia: Jurnal Ilmu-Ilmu Sosial, September 2016, Volume 8 Nomor 2.

Widiarta. G.. "Ide Keadilan Restoratif Pada Kebijakan Penanggulangan kekerasan Dalam Rumah Tangga dengan Hukum Pidana". Ringkasan Disertasi. Program Doktor Ilmu Hukum Universitas Diponegoro, 2011.

Yunus. Yutirsa. "Analisis Konsep Restorative Justice mellaui Sistem Diversi dalam SIstem Peradilan Pidana Anak di Indonesia". Jurnal Rechtsvinding: Media Pembinaan Hukum Nasional, Volume 2 No. 2 Agustus 2013. 